\title{
Sociology of Deviance and Criminology in France : history and controversies
}

\author{
Laurent MUCCHIELLI \\ Aix Marseille Univ, CNRS, LAMES, Aix-en-Provence, France
}

Épreuves non corrigées de l'article paru dans American Sociologist, 2017, ${ }^{\circ} 1$

\begin{abstract}
Résumé
Dans cet article, nous explorerons l'histoire singulière de la sociologie de la déviance et de la criminologie en France, de la fin du 19ème siècle à nos jours. Nous repartirons des années 1880, au moment où les questions criminelles envahissent le débat intellectuel. Nous verrons comment la sociologie s'est construite largement contre les déterminismes biomédicaux, qu'il s'agisse de Gabriel Tarde ou des durkheimiens. Nous verrons ensuite comment la question criminelle a cependant fait l'objet d'une alliance entre les médecins et les juristes durant la première moitié du 20ème siècle, pour développer les premières institutions de la criminologie ou plutôt des «sciences criminelles ». Dans les années 1950-1960, Jean Pinatel tentera d'en faire la synthèse et cherchera en vain à institutionnaliser une discipline criminologique. Mais à partir des années 1970, la sociologie de la déviance a fait un retour fracassant sur la scène scientifique, en liaison avec l'influence de la sociologie de la déviance américaine (l'interactionnisme) et de la critical criminology anglaise. Depuis cette date, ce sont les sciences sociales qui produisent le plus de connaissances scientifiques sur les phénomènes criminels, sur les institutions pénales (police, justice) et sur les politiques publiques de sécurité et de prévention. Pourtant, dans les années 2007-2012, une importante polémique s'est développée au sujet de la nécessité ou non d'institutionnaliser une discipline criminologique en France, en liaison avec le contexte politique néo-conservateur du moment.
\end{abstract}

Keywords : Sociology of Deviance - Criminology - History of Science - Security policies Institutionalization - Controversy - Law and Order ideology 
The state of a discipline - or, more simply, the state of a discourse field and the related academic practices - cannot be understood outside the historical framework of its national genesis ${ }^{1}$. This 'broad picture' view of France suggests a four-period split: (1) paradigmatic assertions and the impossible transdisciplinary dialogue typical of the years 1880-1940; (2) the normative context of the years 1945-1975, and the fresh associations it brought about; (3) the renewed dissociation between professional rationales and transdisciplinary dialogue from the mid-1970s onwards, alongside the considerable development of social science research from the 1990s; (4) finally, we question the current situation and the recent controversy (since 2007) about the renewed, politically motivated attempt at establishing criminology as a full discipline.

\section{Between the biological and the social: the search for a crime paradigm (1880-1940)}

In France, in the 1880s, as crime research was in the process of being institutionalized as a new scholarly discipline - a trend that pervaded the entire Western world-, the scientific discourse was dominated by the question of the individual genesis of crime. This issue was almost exclusively addressed from a biomedical perspective, through various theories purporting to somehow identify in certain individuals the existence of "natural" (hereditary) predispositions for aggression, crime, or even flatly "Evil" (Nye, 1984; Pick, 1989; Blanckaert, 1994; Renneville, 1997, 2003; Foucault, 1999; Mucchielli, 2006). The novel discipline that emerged in France at the time was not called "Criminology" by its proponents yet, but "Criminal Anthropology" ("Anthropologie criminelle"). However, some French medical doctors - including Alexandre Lacassagne (1823-1924), Professor of Forensic Medicine at Lyon University School of Medicine and main promoter of the new field frequently alluded to the "social factors of crime" and did challenge, at least in part, Cesare Lombroso's concept of the born criminal. The "Criminal Anthropology" designation mainly aimed at taking strategic distance from the Italian school, from which they were in fact intellectually - e.g. professionally - very close (Mucchielli, 1994a; Renneville, 1995). Only in the then budding field of social science could proper research on crime as a social phenomenon be seen emerging at the time.

\footnotetext{
${ }^{1}$ In this paper, we resume and actualize researches published in French (Mucchielli, 2014).
} 


\section{Crime as a social phenomenon}

During the 1890s, non-medical research endeavours focussing on the social dimension of crime were scarce and did not put forward any sociological methodology. Gabriel Tarde (1843-1904), for example, offered in his extensive works a great many thoughts about crime and penalty, through a series of books of which some were internationally acclaimed, in particular La criminalité comparée (1886) (Comparative Criminality), and La philosophie pénale (1890) (Beirne, 1987). He had strongly contested the biological paradigm of Lombroso' school (Borlandi, 2000). Moreover, despite occupying prominent positions from 1894 onwards (as head of the Judicial Statistics department at the Ministry of Justice, and codirector of Lacassagne's journal, Archives d'anthropologie criminelle), and being elected to Collège de France in 1900, Tarde never trained any scholars or launched any research programme (Mucchielli, 1994b).

Besides Tarde, several intellectuals devoted at least some effort to crime study at the time. For a while, the most active and creative among them was Henri Joly (1839-1925), who taught "criminal and penitentiary science" at Paris University School of Law, starting 1887, and published a string of noted books at the end of the 1880s (Veilt, 1994). The dominant theme running through his criminological works was moral degradation rather than biological lowliness. To him, the criminal was a "misled man", not a "survivor of primitive ages". This degradation itself partook to the rootlessness of modern man, forced to leave his family, his village, his trade, to go and seek a job in the anonymity and isolation of the big city. Joly set up to prove his theory using countless geographical maps, published in his 1889 book La France criminelle (Criminal France). Joly's works, however, rather failed to reach a broader audience.

One has to turn to the group founded in 1897 by Émile Durkheim (1858-1917) around his journal L'Année sociologique to first notice the emergence of a trend towards criminal sociology. This group brought together young philosophers who were convinced that sociology needed to be endowed with a proper scientific agenda based on autonomy from other sciences (Mucchielli, 1998). Among them, Gaston Richard (1860-1935) was picked by Durkheim to head the "Criminal sociology and moral statistics" section of the journal. It fell upon him to lay the foundations for a sociology of crime, in a complete turnaround to the biologization of behaviours that prevailed at the time. The work accomplished around Richard, from a critical point of view (see for example the notion of "criminogenic environment") as well as through its scholarly contribution proper (historical analysis of shifting value and work systems, and their effect on criminality), constitutes an attempt at 
gradually building both the object and the agenda of a criminal sociology (Mucchielli, 1994b). As compared to the influence enjoyed by Durkheimians in other scientific spheres at the time, however, their critical work in the field of criminology was a failure. There are at least three reasons for this: first, the considerable strength and autonomy of the psychiatric circles, whose discourse increasingly prevailed once the fad for criminology subsided, and whose alliance with magistrates was already institutionalised. Then, the medical world displayed remarkable cohesion around its mainly hereditarist concept of crime. Finally, sociological research almost vanished from this area at the turn of the century, after Richard left the Durkheimian group.

\section{From criminal anthropology to psychiatry: a shift in medical criminology}

While the works of Italian and French criminal anthropology scholars reigned almost supreme in the years 1880-1895, the last decade of the century saw the alienists gradually regain the upper hand on the medical discourse, a supremacy that can be explained in several ways. While the sheer overall volume of publications is hardly a sufficient criterion, a closer look at international conferences on criminology, in terms of both membership of the organising committees and quality of speakers, also gives a measure of the institutional weight of the various groups. Even though the "criminal anthropology" designation stayed, academics who defined themselves as anthropologists declined steadily in numbers. As criticism against the criminal type and the relevance of anthropometrics swelled in all countries, the third International Criminal Anthropology Congress, held in Brussels in 1892, signalled a first symbolic break up, as the Italian delegation refused to attend, considering their ideas to be inadequately represented. Indeed, the Brussels Congress can be seen as an "artillery barrage" operation. The French (Debierre, Lacassagne, Manouvrier, and Tarde); the Dutch (Jelgersma, Masoin, and Van Hamel); the Belgians (Cuylits, Dallemagne, Houzé, and Struelens); Benedikt, of Austria; as well as the Germans (Näcke and Von Liszt): these scholars unanimously agreed that, although physical stigmata may frequently characterise criminals, they could not be used to define any individual as a criminal or be construed to infer general roots to criminal behaviour.

At the turn of the century, except for the rearguard of Lombroso's followers, it seems that only Lacassagne and his students still believed in the virtues of anthropometry.

\section{Hereditarist theories: from degeneration to constitutionalism}

Throughout the years 1880-1914, mental health circles largely shared the vision of inneism 
and hereditary determinism used by anthropologists in their constructs, albeit expressed in different ways. Their favourite model was degeneration theory (Pick, 1989; Dawbiggin, 1991 ; Renneville 1997). Charles Féré and Valentin Magnan were the most active French alienists at early criminal anthropology congresses. Féré was the first to get involved in criminology discussions, with his 1888 book Dégénérescence et criminalité (Degeneration and Criminality). Magnan, however, established a more authoritative reputation. A mere general practitioner at Saint-Anne Hospital in Paris, outstripped by Ball in the 1877 race for the Chair of Mental Illnesses at University of Paris School of Medicine, his diligent attendance at criminal anthropology conferences may have been mainly motivated by the will to build the international reputation he was lacking. He certainly did take a very early interest in social problems while working on alcoholism, however. Whatever the case may be, Magnan came to the criminal field intending to defend and propagate the theory of degeneration he had inherited from his first master, Prosper Lucas.

At the Brussels 1892 congress, Magnan presented a report entitled "Morbid Criminal Obsession", in which he distinguished between the "delusional insane" ("aliénés délirants") and the "higher degenerate" ("dégénérés lucides"), pushed by "morbid obsessions" that the alienist should endeavour to identify and describe: homicide, theft, pyromania, or sexual perversion. Magnan's report serves as yet another illustration of the ultra-deterministic view of biology held by alienists of the time. He identified for example four different categories of sexual perverts, based on features exclusively pertaining to brain physiology: The "spinals", whose unconscious acts were motivated by elementary organic reaction mechanisms; the "posterior spinal cerebrals", for whom the mere sight of an individual of the opposite sex sparked the sexual impulse; the "anterior spinal cerebrals", who simply displayed some specific form of perversion, located in the anterior cerebral cortex, which gave an abnormal orientation to their desire - e.g. either applied it to inappropriate subjects (incest, homosexuality, zoophilia) or through inappropriate channels (exhibitionism, mutilation, etc.); and finally the "anterior or psychic cerebrals" who, on the contrary, only functioned at the frontal level, as their conscious desire failed to trigger normal physiological functions.

Physiological causality, as we can see, was hugely influential in the psychiatric theories that dominated the turn of the century. Magnan's successor, Ernest Dupré, worked from the same assumptions on concepts such as "morbid constitution" and "constitutional perversity"; and it is the very same inspiration that thoroughly guided the works of Georges Heuyer on child psychiatry, at least during the interwar period (Lefaucheur, 1994).

\section{The situation during the interwar period}


It is hard to see where exactly sociological ideas might have fit into such a paradigmatic framework.

Generally speaking, French scholarship became less fertile during the interwar period. At the international level, sociological thought emanated mainly from the U.S., the Chicago School in particular. Their research, however, remained little known in France. Maurice Halbwachs (1877-1945) who was, along with Marcel Mauss, the key man of the interwar Durkheimian system, was interested in suicide and not criminality. In addition, his vision of the Chicago School and its research on the city was rather aloof (Marcel, 1999; Topalov, 2006). While “judicial and moral sociology" studies always remained central among Durkheimians (such as Louis Gernet, Paul Fauconnet, and Georges Davy), any interest for crime in modern societies disappeared almost entirely from interwar French academic sociology.

In fact, during the interwar period, the field of "criminology", as it was called - or "criminal science", or even "penitentiary science" - was dominated by jurists, along with medical practitioners appearing in court (forensic and psychiatric experts) (Kaluszynski, 1994). This trend actually started before WWI in academic circles, with certain law schools offering courses covering criminal law, criminology, and/or penitentiary science (Pinatel, 1957, 417). This triggered new dynamics in legal studies, in an institutional alliance uniting doctors and jurists, with the latter calling the shots this time. On the academic front, this alliance was finally recognized in 1922 with the creation of the Paris Institute of Criminology, jointly run by the Paris Law and Medicine schools, with a four-pronged curriculum: (1) criminal law, (2) forensic medicine and criminal psychiatry, (3) scientific police, (4) penitentiary science. Ever since then, criminology, or "criminal science", has continued to feature in law schools, as a scholarly appendix to penal law.

In 1936, criminology was given a proper means of expression with the Revue de science criminelle et de droit pénal comparé (Review of criminal science and comparative penal law), headed by two Professors of the Paris Law School (Louis Hugueney and Henri Donnedieu de Vabres), with a committee comprising, besides other jurists, psychiatrist Claude, forensic scientist Balthazard, as well as Sannié, director of the Scientific Police Institute (and a Professor at Paris School of Medicine).

Finally, on a paradigmatic level, after the revival of psychiatry at the expense of criminal anthropology, the interwar in France was mainly characterised by the gradual ushering in of psychoanalysis (Mucchielli, 1994c). Pioneering French psychoanalysts (Hesnard, Laforgue, Marie Bonaparte, etc.), however, in keeping with a literal understanding of Freud's writings, all enhanced the criminal nature of Man, its "aggressive instincts" and "original violence", 
with analyses consistently revolving around the conventional psychiatric wisdom of the times: the "constitutional factor", the "physiological foundation" of criminal conduct. Such a paradigm made any convergence toward social science fairly difficult at best. Moreover, these initial psychoanalytic attempts at criminal science were mainly based on pathological case studies (paranoid delirium, crimes of passion).

\section{The era of dialogue and its normative context (1945-1975)}

The end of WWII signalled a new dawn for human sciences, which were increasingly involved in social and political life. In the legal sphere, this new philosophical era translated in particular into the principles of the "new social defence", developed in France by Marc Ancel (1902-1990) to the point where it offered a common ground to many jurists during the years 1950-60 (Levasseur, 1991; Enguéléguélé, 1998). In addition, the socialist ideal (in the broadest sense) had growing influence throughout Europe. In the field of penal policy, this quite naturally involved a willingness to focus on education (or re-education) and prevention, to offer psychological support to challenging teenagers, and to deeply reform the prison system (Faugeron, 1991b). Still, this movement was neither fundamentally new, no absolutely prevailing. Old trends persisted and did contradict it at times. But as we will see, the scientific sphere offers three examples of the bridge-building potential allowed by this common cultural ground: first, as jurists opened up to sociology; second, as a transdisciplinary dialogue developed around the issues of juvenile delinquency; and third, as a theoretical dialogue seemed - at least for a while - to have been sparked between sociology and psychology.

\section{Keeping traditional criminology alive}

One example of traditional criminology staying very much alive is the thought and action of Jean Pinatel (1913-1999) from 1950-1980. In his capacity of Inspecteur général de l'administration pénitentiaire (Inspector General of Prisons), Pinatel was a member of the Amor Commission, which was in charge of reforming the prison system in 1945. He first introduced himself as an expert in "criminal science", then in "criminology", which he taught for many years at the Paris Institute of Criminology. In the immediate aftermath of the war, and for several decades, he was one of the main contributors to the Revue de science criminelle et de droit pénal comparé.

Pinatel defended criminology as it was practiced during the first half of the century - starting with biology, following up with psychopathology and, in fine, possibly borrowing from 
sociology a few general frameworks/contexts that more or less favoured criminality. Such was the outline of his courses; and such was the scientific agenda that informed the International Congress of Criminology organised in Paris in 1950 by Pinatel, drawing on his membership of the International Society for Criminology, which he dominated for almost thirty years (Pirès, 1979). This is understandable, given that Pinatel had defined criminology as a study of the criminal, whose core task was to study the "criminal personality" in order to subsequently diagnose the "dangerous state", thus safeguarding society from trouble (Pinatel, 1960). Although Pinatel, in the 1970s, facing the rise of sociological criticism and "critical criminology" in the Western world, partially conceded to the sociological approach, these were mere "ad hoc changes", to borrow the words of Thomas Kuhn (2012), which never seriously challenged the theoretical core of the classical "paradigm" defended by Pinatel.

Generally speaking, post-war French law schools witnessed a strong increase in the interest for criminology. In the 1960s, specialised curricula were offered in Paris (at the Institute of Criminology as well as at the Criminal Science department of the Institute of Comparative Law, headed by Marc Ancel and Yvonne Marx), Aix-en-Provence (Penal Science and Criminology Institute, headed by Raymond Gassin), Bordeaux (Criminal Science Institute headed by Jean-Pierre Delmas Saint-Hilaire), Montpellier (Criminal Science Institute headed by J.-M. Aussel), Poitiers (Criminal Science Institute first headed by Pierre Couvrat, then by Jean Pradel), Toulouse (Criminology and Penal Science Institute headed by Roger Merle), and Lille (Institute of Criminology headed by Georges Levasseur), as well as Strasbourg (Criminal Science Institute headed by Jacques Léauté), Nancy, etc.

\section{The dialogue between jurists and sociologists and the revival of criminal sociology}

That said, the sociological approach of the criminal phenomenon also found a favourable echo with many jurists-criminologists of the time, particularly in and around Durkheimian circles. L'Année sociologique, the twice reborn journal (it reappeared in 1948), was central to this renewed discussion, whose main supporter was Henri Lévy-Bruhl (1884-1964). In this new journal, he was in charge of the "sociology of law and moral" section, along with Georges Davy. Lévy-Bruhl put crime studies fairly high on his research agenda, considering that "a social ensemble best reveals its personality through its attitude to crime". As early as 1950-51, under the auspices of CES (Centre d'Études Sociologiques), he conducted a "criminology survey", subsequently presented at the $2^{\text {nd }}$ International Congress of Criminology, entitled "Statistical survey of breach of trust". Simultaneously, a "criminal sociology research group" was born, with Lévy-Bruhl as a guardian figure - however, André Davidovitch (1912-1986) 
quickly became one of the most active members, before gradually taking over the leadership (Marcel, Mucchielli, 2006). This group, built from a handful of scholars and students attracted to EPHE (École Pratique des Hautes Études-Practical School of Advanced Studies) by the teaching of Lévy-Bruhl, quickly exceeded this framework, gradually expanding until it became what had to be called a small team. Its 1956-57 agenda shows, beyond Davidovitch's prime study ("Fraud and Bad Cheque Issuance"), that Constantin Oeconomo was researching the "Psychosociological and sociological aspects of war: special delinquency in the army"; while Dimitri Kalogeropoulos, a graduate from Paris Institute of Criminology and the Institute of Comparative Law, was working on "Blood crimes"; and René Benjamin, a supply teacher at CES, was announcing a research project exploring "resocialising delinquents: the role of the religious feeling". New scholars flocked during the following years; various studies were launched - about incest (Denis Szabo, whose doctoral thesis would later be entitled "Crimes and cities") or about criminality in Paris (Vasile Stanciu). The dynamics were triggered: a new, hybrid discipline, "criminal sociology", was born-albeit, paradoxically, thanks to a jurist who initiated the institutional blending with sociology.

This synergy, however, was stopped in its tracks when Lévy-Bruhl died in 1964. The event prompted a split, and Lévy-Bruhl's "sociological heritage" was picked up by a team built around Davidovitch. Law scholars followed Jean Carbonnier (1908-2003), who played a pivotal role, replacing Lévy-Bruhl at the board of l'Année Sociologique, drawing together many of his former students, and co-founding a research group with Georges Levasseur"Research and measure of institutional and normative transformations of contemporary society" - which, in January 1968, became the Laboratory for criminal and penal sociology of Paris II University. Why did this split happen? Theoretical divergences were noticeable. Carbonnier had his own particular idea of judicial sociology: although certainly linked to an intellectual posture that approaches the judicial fact "from outside", it should only do so with an aim to help the legislator. In that sense, while he claimed some Durkheimian affiliation, in the world of jurists this intellectual lineage came "at little cost", since he somehow managed to append judicial sociology to law studies (Soubiran-Paillet, 2000). Davidovitch had other views, more faithful to the Durkheimian paradigm, which he developed within the small unit he led at CES until his retirement in 1981: the "Criminal Sociology Research Unit". There, Davidovitch carried out a string of major research works on judicial statistics, on the activity of Prosecutor's office bodies, on the mapping of criminality in the city, as well as on several specific crimes (bad cheques and traffic delinquency in particular). Over the years, he was able to refine his analysis system within the framework of a well-defined research programme, "observing the judicial machine as it copes with criminality, and analysing 
criminality as a product of that machine. These products, insofar as they are the outcome of selective interventions, convey in objective terms (they are indicators) the attitude - or attitudes - of magistrates, at the various levels of the judicial apparatus, as they confront the various types of crime". During many years, he was also a noted columnist for L'Année sociologique.

\section{Developing a transdisciplinary area: youth delinquency}

Youth delinquency was one of the main areas of convergence and debate for academics and professionals of the field after 1945 (Tétard, 1985; Bantigny, 2008; Yvorel, 2014; Jurmand, 2016). In addition to the tradition of child psychiatry initiated in particular by Heuyer and his students, juvenile court judge Jean Chazal de Mauriac (1907-1991), who was quite close to Marc Ancel, played an important role in this area as early as the Vichy period, but mostly after the war. Later on, that theme developed mainly from an institutional point of view, given the opening, in 1958, within the Ministry of Justice, of the Training and Research Centre for Correctional Education (CFR-ES - Centre de Formation et de Recherche de l'Éducation Surveillée) in Vaucresson (in the suburbs of Paris). The creation of this centre was motivated by the reorganization of juvenile courts through the ordinance of Feb. 2, 1945 on delinquent youth: after establishing a new Office for Correctional Education at the French Ministry of Justice and implementing a string of supervisory measures for endangered and delinquent youth, a training centre was required for newly hired employees.

In 1958, the training activities were strengthened by the addition of a research unit which subsequently grew on its own and was significantly reinforced from 1964 onwards, when psychologist Jacques Sélosse was chosen to lead the research effort. Vaucresson quickly became the most important criminology research centre in France, with a transdisciplinary team (psychologists, sociologists, psycho-educationalists, statisticians, plus one neuropsychiatrist, one jurist, and one demographer), albeit slightly dominated by clinicians. In 1963, the centre finally launched its own journal: the Annales de Vaucresson. The following ten years were the golden age of the Vaucresson centre. At the onset of the 1970s, research developed along five lines: (1) analysing juvenile "social inadequacy" phenomena - mainly gangs and delinquency (car theft, drug use, violent crimes); (2) studying the methods of intervention of youth workers with juvenile delinquents; (3) evaluating the outcomes of this rehabilitation work; (4) researching the general roots of juvenile delinquency growth (school and economic developments in particular); (5) continuous education methods as applied to youth workers. From a "socio-criminological" perspective, the first line delivered the most in 
terms of new information. Some of this research helped enhance new aspects of juvenile delinquency in a consumer society. This particularly holds true of research on car and motorcycle theft, which showed that the point was often not so much appropriating goods, even in order to sell them, as fun or utility (for a night); the main danger being the fact that such a behaviour was likely to generate traffic accidents.

In the area of juvenile delinquency, the Vaucresson centre stands as the main transdisciplinary research attempt known in France. However, from the end of the 1970s onwards, this attempt gradually faded away.

\section{Social sciences and psychological sciences: a dialogue at last?}

The years 1945-1975 witnessed a historically unprecedented opening-up phenomenon that made it possible to start building bridges between sociology and psychology. Before WWII, irreconcilable paradigms would pitch sociology, totally impervious to individual psychology, against psychology, which appeared unable to get rid of biological determinism. This situation, however, quickly evolved after the war, as first illustrated by Daniel Lagache (19031972) (Mucchielli, 1994c). Lagache was strongly influenced by phenomenology during the 1930s (including both Jaspers and Minkowski in general psychopathology, as well as Belgian psychocriminologist Étienne De Greeff), and also felt the influence of psychosociologist Kurt Lewin. Thus it is that, during the 1950s-60s, he came to develop a theory of criminal psychology that entailed a strong social dimension. However, being at the time also highly involved in psychoanalysis, he apparently lacked a partner to build this frontier at that point in history.

Still, two other clinicians did more directly invest the field of criminology, building partnerships with social scientists (Mucchielli, 1997). One is Marcel Colin, bringing along with him what would come to be known, from the first French Congress of Criminology (Lyon, 1960) onwards, as the "second school of Lyon" - the team he later lead at Lyon Medical School's Institute of Forensic Medicine and Clinical Criminology. Colin - who was deeply influenced intellectually by Sartrian existentialism and who also leaned towards interactionism in many respects, in addition to being closely linked to English antipsychiatrists - strongly supported the idea that the clinic should have a fundamentally therapeutic purpose, opposing the deterministic concept of "criminal personality", a phrase that, according to him, should be "banned from psychiatric vocabulary." He became indeed a fellow traveller of both French sociologists and European critical criminologists, especially around the network that was built during the first half of the 1970s, founding in particular the 
journal Déviance et société. The same goes for De Greeff's pupil Christian Debuyst, a Professor of Criminology in Leuven (Belgium), who, in the 1960s-70s, published empirical research enhancing the scholarly potential of a convergence between phenomenology and interactionism, and who also wrote seminal texts condemning such concepts as the "criminal personality" and "dangerosity". Debuyst was himself, in the most practical sense and to this very day, a fellow traveller of deviance sociologists and critical criminologists. These towering figures of past decades' criminological clinic, however, had no worthy successors. Ever since the 1980s, the scientific field has evolved in such a way as to either not allow such convergence, or even provoke new clashes.

\section{Institutional growth, the estrangement of disciplines and the supremacy of social science research $(1975-2000)$}

From the end of the 1960s onwards, research in criminology enjoyed a new institutional boom, owing to a purposeful research policy initiated by the French Ministry of Justice (Mucchielli, Marcel, 2002). It also received significant support from the General office for scientific and technical research (Direction générale à la recherche scientifique et technique). In addition to the Vaucresson centre, the Chancellerie created in 1964 the National Centre for Penitentiary Studies and Research (Centre National d'Études et de Recherches Pénitentiaires - CNERP), and then, in 1968, the Penal and Criminological Studies Service (Service d'Études Pénales et Criminologiques - SEPC). To supplement this segmented development and support these research centres, two coordinating and fund-raising structures were created: 1968 saw the advent of the Coordination Committee for Research in Criminology (Comité de Coordination des Recherche Criminologiques - CCRC), a 21-member body chaired by Paul Amor; followed the year after by the Research Coordination Service (Service de Coordination de la Recherche - SCR).

While CNERP never really took off as a research centre, SEPC was to usher in the third age of criminal sociology in France.

\section{A sociology of social reaction}

SEPC was initiated by Philippe Robert (a magistrate with a $\mathrm{PhD}$ in sociology from Bordeaux University) and born at the end of 1968, reporting to the Office of Criminal Affairs and Pardons (Direction des affaires criminelles et des grâces) at the Ministry of Justice. In 
addition to its expected research output, its other assignments were the general secretariat of CCRC, as well as managing the Compte général de l'administration de la justice (judicial statistics). SEPC enjoyed a quick growth, so much so that it came second only to Vaucresson among research centres, and gradually conquered partial autonomy from the Ministry, in terms of both processes and output, soon co-reporting to CNRS, the National Centre for Scientific Research (Centre National de la Recherche Scientifique), resulting in a peculiar positioning in the field of French criminology. It swiftly established strong network ties in Europe and North-America (e.g. French-speaking Canada), which chiefly resulted in the creation of a new journal in 1977. Déviance et société was born in a peculiar intellectual atmosphere marked by growing controversy surrounding the penal system, and the arrival of interactionism (the second Chicago School and its labelling theory) and "critical criminology" (Mucchielli, 1997).

Some of SEPC's initial research areas were inspired by the direct needs of criminal justice (forecasting registered criminality; maintaining administrative statistics; monitoring apparent foreigner delinquency or drug trafficking). Others rather focussed on the analysis of institutional processes (studying the costs of crime or the penal handling of business criminality; constituting collective rape as a category), and studied the image of the institution in society (studies on social representations of the criminal justice system). However, beyond those headings, which were quite commonplace in the field of criminology at the time, SEPC was actually taking a critical stance. In 1973, Philippe Robert published in l'Année sociologique (which he had joined thanks to Davidovitch) a text announcing the crisis of positivist criminology - in his own words "criminologie du passage à l'acte", literally "acting out criminology" - i.e. aetiology theories. First, he argued that these bio-psychological research studies were based on non-representative crime samples. He then proceeded to introduce labelling theory, stating that the process through which an individual steps from occasional to chronic delinquency "stems from a stigmatization of the social reaction that takes place when the public classifies as a deviant someone who merely engaged in a deviant act." From this perspective, criminology could be turned into a "science of social mechanisms of rejection", hinging on the analysis of the penal system. Robert then tried to launch a relevant research programme, based on two questions: how does society create norms; and how does it sanction them? Besides traditional empirical fields such as the analysis of penal statistics (from policing to prison) and the study of the social representations of justice, SEPC researchers gradually developed research on the mechanisms of transfer toward judicial authorities, and on the genesis of penal norms (legislative sociology) - later on even establishing ties with historians on the latter theme. Throughout the 1970s and 1980s, SEPC 
thus produced cutting-edge research in this area, in a well-defined paradigmatic framework which de facto excluded any potential collaboration with psychological sciences. Robert's position has always been that criminology should be considered a discipline without an object, whose transdisciplinarity was a mere façade, devoid of any heuristic value; by contrast, he preferred a sociology of crime, rooted in a given paradigm and in a cumulative empirical research approach.

Without even mentioning political agendas that led some to reject any non-external perspective on research objects (such as prison, for instance), discrepancies in professional rationales were too critical among the various players for any meaningful research collaboration to take place.

\section{The evolution of the institutional context, 1980-2000}

In May 1981, left-wing leader François Mitterrand became President of the French Republic, in a dramatic upset that created the conditions for an actual reorganization of research within the Ministry of Justice - the project had been in the air for several years, but never implemented. As a result, both CNERP and SCR disappeared, and a new convention was signed between the Chancellerie and CNRS in 1983. Only CFR-ES and SEPC remained: the former became the Vaucresson Centre for Transdisciplinary Research (Centre de recherches interdisciplinaires de Vaucresson - CRIV), while the latter was called the Sociological Research Centre on Law and Penal Institutions (Centre de recherches sociologiques sur le droit et les institutions pénales - CESDIP). In addition to boasting a rather long-standing relationship with CNRS, CESDIP was the main recipient of the redeployment of staff from late CNERP, which added penitentiary issues to its research agenda. CRIV, however, found the situation much less favourable, challenged as it was by a structural crisis that it never really managed to overcome. Outside these two units, most scholars of the field who had been assigned to general-purpose research centres felt rather isolated, so that over the 1980s, CESDIP gradually emerged as the only crime-orientated social science research centre, which it remains to this day. Furthermore, it managed to regularly push fresh ideas, developing in particular pioneering - in France-victimisation surveys, as well as, from the 1990s onwards, research studies on the feeling of insecurity, and policing research.

The 1990s partially challenged this situation, with the institutional development of three new areas of research, once again directly spurred by State requests:

- First came research on drugs, at the beginning of the 1980s, with a dramatic decade-long growth. This phenomenon was linked to strong institutional demand motivated by the 
increase in drug consumption and the AIDS epidemic. An interministerial drug-fight structure was implemented in 1982, which gradually became autonomous. 1993 saw the creation of a Public interest group called French Observatory of Drugs and Drug Addictions (Observatoire français des drogues et des toxicomanies - OFDT), which goes to show that government funding was a lasting trend and the will to stabilise statistical indicators genuine. A research network ("Psychotropes, Politiques, Sociétés") was born in 1994, followed by a CNRS laboratory in 2001 (called CESAMES - Centre de recherche Psychotropes, Santé Mentale, Société).

- The other area that developed dramatically during the $1990 \mathrm{~s}$ is policing research. The creation, in 1991, of the Institute for Higher Studies on Interior Security (Institut des hautes études de la sécurité intérieure - IHESI) provided significant funding for this research. The institute, for that matter, has become quite an important player of the field as a whole, funding research and publishing a journal that boasts numerous academic contributions (the Cahiers de la sécurité intérieure). However, its dependence on the political power subjects it to periodical turmoil.

- Finally, the Ministry for Town Planning (created in 1990) also provided important support for research on delinquency throughout the 1990s, while the Interministerial delegation for road traffic safety also funded many studies on traffic crime.

Hence, from the mid-1990s onwards, research production was scattered among several, diverse places. These issues were extensively discussed at CLERSÉ (Lille Centre for Sociological and Economic Research and Studies of CNRS, Lille 1 University) around Dominique Duprez; at GRASS (CNRS Social and Sociability Analysis Group, Paris 8 University) around Francis Bailleau; and at CERSA (CNRS Administrative Science Study and Research Centre, Paris 2 University), headed by Jacques Chevallier. Moreover, crime research never totally deserted law schools - some jurists still define themselves as "criminologists". Most active among them is Robert Cario, in charge of the "Jean Pinatel Criminal Science Unit" at Pau University, and publishing director of the "Sciences criminelles" series at L'Harmattan publisher.

\section{The main areas of social science research, 1980-2000}

Despite the Vaucresson centre crisis, the development of sociological research during the 1980s prompted several authors to re-appropriate the subject of juvenile delinquency while researching the subject of working class youth. Such was the case for "Jeunesses et Sociétés" (Youth and Societies) network, which gradually drew together dozens of academics and 
researchers in a think tank mostly influenced by the work of Pierre Bourdieu - one example is sociologist Gérard Mauger and his seminal work on "youth gangs". Others include several scholars from Alain Touraine's circle of influence, who worked on collective action in working class neighbourhoods (François Dubet, Didier Lapeyronnie, Adil Jazouli).

Then, as social developments put such issues as juvenile delinquency and rioting under the spotlights of the media/political stage again and sparked fresh institutional demand (especially around the policing category of "urban violence"), scholarly output increased, in the second half of the 1990s in particular. Research studies, however, in a departure from the previous decade, focussed mainly on quantitative methods, given the ever-growing impact of statistics and "expertise" in mainstream media. Here, we should mention Hugues Lagrange and his work on victimisation and juvenile delinquency; as well as Sébastian Roché's 1999 selfreported survey on delinquency; or the emergence of "school violence" as a sub-theme again, due to a strong demand from the political sphere (Eric Debarbieux). At the turn of the century, Laurent Mucchielli's work first queried the influence of this political and media "agenda building" around "youth violence", before starting new research on criminal behaviour (homicide, rape), juvenile delinquency, and the riot phenomenon.

A contrario, upper class delinquency (the so-called "white-collar crime"), either in the private or in the public sector, has never ranked too high on the French collective research agenda. Only political and administrative corruption attracted the shared attention of political scientists and sociologists at some point (at the end of the 1980s, to be precise), because this phenomenon happened to be topical in the media at the time.

These new trends notwithstanding, research during the years 1980-2000 kept focussing on the penal system (see research statements by Faugeron, 1991a ; Renouard et alii., 1992 ; Faget, Wyvekens, 1999 ; Mucchielli, 1999a), albeit in a somewhat patchy way, given the scarcity of research on sentencing processes. Conversely, research about criminal justice professions developed sharply. Certainly the most scrutinized area was policing-magistrates, lawyers, and social workers have been comparatively subjected to fewer studies. Finally, one should mention the emergence of research on private security agents, and more recently on ombudsmen. Then again, in the wake of Michel Foucault's though-provoking 1975 book Discipline and punish, and thanks to new partnerships involving historians, sociologists, and demographers, prison studies have always been a forte of French scholarship: statistical research (on prison population; on how this population's movements hinged on economic conditions; on the penal and social follow-up of cohorts); historical research (on the history of prisons and the living conditions of inmates); quantitative research on training, attitudes, and 
behaviours in the daily life of all prison stakeholders (officers as well as inmates); specific research on police custody.

Finally, as mentioned above, victim research became central from the mid-1980s onwards. French scholarship had fallen significantly behind North-American research and was missing out on theoretical discussions spurred by victimology. CESDIP researchers had developed their surveys with the aim of creating some form of sociology of penal control, focussing in particular on how victims dealt with police forces and the judiciary. Gradually, however, these studies came to be considered as a mere tool for improving the knowledge and statistical measure of delinquency, furthering the picture drawn by police forces (recorded crimes).

\section{Controversy about the political return of criminology (2002-2012)}

Today, at a time when, all over the Western world, State governance as well as the political debate in the media seem to focus more and more on the "war on crime" and a new form of social control called "risk management" (Garland, 2001 ; Simon, 2007), many authors emphasize the important issues raised by these developments and their questioning of the theoretical foundations, institutional workings, and research orientations of criminology (Garland \& Sparks, 2000 ; Hillyard \& al. 2004 ; Chunn \& Menzies, 2006 ; Zedner, 2007). France has managed to shun the issue for all the reasons we had presented in this paper. As a matter of fact, however, a new project of constituting such a field is currently under way, fueling the very issues already under discussion in other western countries - on an even more radical note maybe.

\section{Toward a State Criminology in France?}

While "political demand" had strongly stimulated research during the 1980s and 1990s, one of the salient features of the years 2002-2012 in France was the growing attempts at political control of knowledge production (Mucchielli, 2014). Following the 2001-2002 election campaign - largely dominated by the theme of "insecurity" - and the 2002 change of government (when the Right was returned to power), one has to observe that IHESI (henceforth INHES - Institut National des Hautes Etudes sur la Sécurité) was subjected to a political and ideological "overhaul", as most of its scholars were dismissed (Mouhanna, 2009). Les cahiers de la sécurité, which had become a social science journal, returned to its 
initial condition of governmental outlet. Nicolas Sarkozy (then Minister of Interior) subsequently implemented the long-deferred creation of a National Observatory of Delinquency (OND), which was integrated to this Ministry. Leadership of OND was handed over by the Minister to Alain Bauer, owner of a private security consulting firm (more details after). Finally, after N. Sarkozy was elected President of the French Republic in 2007, A. Bauer was entrusted with a "Mission on strategy training and research", whose objective was to reorganize all units of security expertise scattered among various ministries into one single, government-controlled institution, while also trying to gain better control over academic and scientific research. The report, published on March 20, 2008 (Bauer, 2008), suggests "gathering" all research on security and penal justice matters within one and the same, politically controlled, public organization. Immediately thereafter, Mr. Bauer was made responsible for a "foreshadowing mission", a section of which was to be dedicated to exploring the "development of criminology in higher education" and entrusted to Pierre Tournier, a statistician and senior research fellow at CNRS, member of the above-mentioned mission, and former President of the French Society of Criminology (Association Française de Criminologie - AFC), whose members are mostly practitioners (jurists, psychologists, doctors), and whose current President is a magistrate. Ever since, these gentlemen have been organizing panels on the "development of criminology in higher education", some of them even requesting the creation of a new, dedicated section at the National Council of Universities (Conseil National des Universités - CNU) ${ }^{2}$. Their aim is to put an end to a "French exception" (the lack of criminology as a field) which, according to them, stands in the way of "transdisciplinary" work on the "crime phenomenon".

The Bauer's report recommended establishing a "High Council for Training and Strategic Research" (Conseil supérieur de la formation et de la recherche stratégique - CSFRS), dealing directly with the President of the Republic on policy matters, even though, from an operational point of view, it would in fact report to the Prime Minister. In an address given as early as January 3, 2008, the President announced his decision to establish such a council, supported by an advisory committee whose members he would appoint himself ${ }^{3}$. The presentation offered on the "Vie publique" official website indicates that this council, which is intended to "define a new brand of strategic thinking", will also be entrusted with "uniting the

\footnotetext{
${ }^{2}$ The CNU is the national body that is in charge of the career management aspects of academia in France, including qualifications and recruitment. It is divided into discipline sections.

${ }^{3}$ http://discours.vie-publique.fr/notices/082000053.html
} 
academic community and facilitating the dialogue between public and private organizations" 4 .

The idea of developing a new academic discipline called "criminology" was thus conceived within the framework of this project. Indeed, the authors of the report consider that "French academia has not been able, or not wanted, to establish curricula exploring strategic issues on defense and security", even though their necessity is felt in order to "meet the growing needs in expertise" (Bauer 2008, 32). The aims of the authors of the report are subsequently explained, along with their opinion of the quality of the French academic and scientific world, and the way they intend to control and direct it:

"In a global context, ideas bear strategic value. The French research system is still considered as too politicized, which leads to an impoverishment of thinking which, in turn, harms research quality. However, quality of the output is the only way to bring status and audience to research on security. It is necessary to link the actual everyday fight (Ministry) with statistics (OND) and research (interdepartmental institutes /universities)." (ibid. 35, italics mine)

Hence, the report recommends merging several governmental agencies, but also considers amalgamating university and /or CNRS research centers with a view to establishing some kind of mega administrative-academic institute, allegedly modeled on foreign (in particular US-) examples, which the Bauer report suggests should be based, in a symbolic move, at the... École militaire ${ }^{5}$ :

"By grouping the training organizations, the documentation centers, and the departments that distribute and promote our thinking, the École Militaire site could potentially become the intellectual and nerve center of strategic thinking on security. This facility should also become the mandatory checkpoint for research in the field. We must create a proper campus, with a focus on defense and security issues, in order to regroup all the units that help expanding thought, research, and free strategic speech." (ibid. 38)

Our reasoning therefore must take place within the general framework of the will to establish a politically-controlled public agency aiming at grouping all human and material resources available to French research on crime and interior security issues, whatever the academic fields concerned. However, that is not enough: we also need to know how the instigators of this project conceive of scientific research.

\footnotetext{
${ }_{5}^{4}$ http://www.vie-publique.fr/actualite/alaune/securite-pour-nouvelle-pensee-strategique.html

${ }_{5}^{5}$ As the name ('Military School') suggests, l'Ecole militaire, founded at the end of the $18^{\text {th }}$ century, under Louis $\mathrm{XV}$, is home to several public organizations in charge of training (senior) officials from the various Army corps.
} 


\section{A catastrophist view of the world, a police view of science}

In an article about the "new calling" of criminology, A. Bauer and two other authors consider that only some form of "social criminology" is available today, which focuses on "individual deviances" and "aims at enriching or influencing public policies (social, or 'urban' policy)", thus ignoring "what is strategic today: collective forms of criminality (organized crime, terrorism); transnational forms of criminality (cartels, mafias, etc.); crime patterns pertaining specifically to the present state of the world (the "dark side" of globalization) (Bauer, Raufer \& Roucaute 2008,89$)^{6}$. Hence, they call for "an extensive revision of the representations and meaning that currently dominate the phenomenal field of criminology", which incidentally implies that criminology should open up on international relations on the one hand, and "hard science" (chemistry, biology, physics) on the other (ibid. 90). Finally, insofar as it comes to embrace all existing science, this new criminology is definitely reminiscent of what might be called police science, defining threats as well as risk groups or individuals who should be processed. Hence, "new criminology will first and foremost have to watch crime phenomena with a view to early detection" (ibid.91). The idea is to identify "new threats" in order to stop them in time. The primary goal of this "refounded criminology" would be to "answer the following key questions: who are the criminals today (and how do they evolve)? Where are they? How many of them? What are they doing and why?" (ibid. 90). This "new criminology" seems to have a lot in common with the missions of Renseignements Généraux (the French interior intelligence agency). Such a criminologist would be working for a police officer who, coming after him, would be in charge of arresting criminals thus identified. This view of the "new calling of criminology" ultimately turns the latter into a branch of scientific police.

\section{The French Securitarian's lobby}

It is very interesting to discuss the authors' profiles of this paper. Alain Bauer introduces himself as a "Criminologist at the Sorbonne University (Paris I, Paris II, Paris V), at the Gendarmerie Hight Studies Center, at the National Magistrate's Academy, at the National Superior Police Academy, Senior Fellow at the Terrorist Center of John Jay College of Criminal Justice in New York (USA), at the Chinese Criminal Police Academy (Shenyang,

\footnotetext{
${ }^{6}$ It should be observed that the text does not even mention "clinical criminology", which on the other hand, is the only one some other public reports, as well as many authors, are interested in.
} 
$P R C)$ at the Law and Political Science University of Beijing (PRC), at the Canadian Police College": no less than 9 academic-type affiliations destined to hide the fact that, at that time, the author is head of the National Observatory of Delinquency, as well as the owner of a private security firm. One year after, he will success in his strategy of scientific's legitimation, getting a professorship of Criminology at the Conservatoire National des Arts et Métiers by a presidential edict of N. Sarkozy, which has produced at that time a large polemic (Mucchielli, 2014, 118-119). As for Xavier Raufer, former journalist and extreme-right activist (Occident, Ordre Nouveau), author of many books on terrorism and "new threats", he is a lecturer at the Paris Institut de Criminologie, but introduces himself as "Director of Studies and Research, Research Department on Contemporary Criminal Threats, Paris Institute of Criminology, Paris II University”. In Valeurs actuelles magazine, (20 Nov. 2008, p. 27), Mr. Raufer goes as far as signing a column as "Professor of Criminology at Paris II University", which is a usurpation of title as defined and punished by French penal law. Finally, the third signatory, Y. Roucaute, is the only true university professor (School of Law of Paris X University). Himself a former journalist (and former board member of the public television channel France 3), former cabinet member in several right-wing governments, fervent promoter of the Iraq war in 2003, supporter of Nicolas Sarkozy during the 2007 campaign, he was chosen to head the Cahiers de la Sécurité, the journal published by the National Institute of Higher Studies on Security (INHES), a public organization affiliated to the Ministry of Interior.

Thus, those three authors are part of a large securitarian's lobby that try to articulate and promote at the same time this catastrophist view of the world, this police view of science, an always more repressive criminal justice, the development of private security agencies and the interests of conservative's parties on the political arena (Mucchielli, 2010, Rigouste, 2011, Berthelet, 2014). They are for example strongly supported by an association denominated «Institute for Justice ». This association, who presented itself as a think tank on security and justice questions, has been creates on the day next N. Sarkozy electoral victory : its statutes are declared to the Rambouillet's Prefecture on May 11th 2007 (Mucchielli, 2014). And one of the key-actions of this association consist in trying to give a scientific likeness to those opinions and interests, which is a constant strategy of this authors network as shown before. On October 8th 2013, the "Institute for Justice" had organized in Paris an evening show for the initiation of a new journal: the Revue française de criminologie et de droit pénal (French journal of criminology and criminal law). In its scientific board, we found A. Bauer, Maurice Cusson (a Canadian's criminologist), a high retired magistrate, two law professors well 
known for their conservative views (Yves Mayaud et Jean Pradel) ${ }^{7}$. This evening show was also animated by Dominique Perben, former Ministry of Justice between 2002 and 2005.

\section{To conclude}

This major attempt to realize a kind of raid on French academic world has been stopped by the mobilization of many people in this world (included the author of this paper) and finally by the defeat of the conservative party in 2012. The securitarian's lobby has lost a battle, but not the war he conduce with determination to enforce his conception of Law and Order. $\mathrm{He}$ strongly profit of the international ideological context more and more propitious since the end of the "cold war", the revival of neo-conservatism in USA and Europe and the regular occurrence of major terrorist attacks in those countries since New York on 11/9. Each terrorist attack become a pretext for governments to stage-manage its determination by voting new security acts like the actual French "State of emergency" after the October 13th 2015 attacks in Paris. In such a context, there is a increasing risk for social sciences to be more and more solicited and financially encouraged to become a kind of Risk Science as this "new French Criminology". To turn back a last time in history of science, we can perhaps remind the words of the French philosopher Georges Canguilhem about psychologist and the Behaviorist vogue of the 1960s : "By accepting to become, on the model of biology, an objective science of skills, responses, and behaviors, this psychology and its psychologists overlook the necessity of positioning their own specific behavior within the historical context and social environments in which they are offering their methods or techniques and striving to have their services accepted.” (Canguilhem, 1968, 377).

Looking now toward the future, what can we wish? Perhaps two things, one inside the academic institutions and the other looking on outside partnerships.

Sociology of deviance is a very small research's field in France. Around the only research centre based on Paris area (the CESDIP, already quoted in this paper), some academics try to promote this field in more or less informal small teams, with their students, which is limited. Even in the actual context of terrorism threaten, the CNRS has asked for the development of

\footnotetext{
7 For example, Jean Pradel, 70 years old, is still professor of penal law at the Catholic Institute of High Education in La Roche-sur-Yon (a private institution whose «institutional guarantor » is the lord of Luçon in Catholic Church. We can also noted that J. Pradel possess the title of «Chevalier de l'Ordre de Saint-Grégoirele-Grand », a decoration directly delivered by the Vatican. He share this decoration with may other French personalities among we find Patrick Buisson, a former extreme-Right activist and consultant for N. Sarkozy presidential campaign of 2012 (L. Petit, « Le Vatican donnerait-il une consigne de vote déguisée ? », Le Monde des religions, 10 February 2012).
} 
researches on this topic, but hasn't created any academic new position for young researchers. On the side of Law and political science faculties, it exists a dozen of "institutes of criminal sciences" in the universities of Aix-Marseille, Bordeaux, Grenoble, Lille, Lyon, Montpellier, Nancy, Paris, Pau, Poitiers and Toulouse, that have tried to cooperate together after the controversy of 2007-2012, without success ${ }^{8}$. But they are mainly devoted to the teaching, rarely to empirical researches, and very rarely in association with sociologist. Furthermore, criminal law, in France, belong to private law and stay a secondary part of it, clearly downgraded in the lawyer's world (Gassin, 1991; Lazerges, 1991), which is a kind of archaism for a part of law so strongly public, more and more dependant with European and International laws and so much debated in public debate. In such a hard context, the main way to develop scientific researches on crime and criminal justice is probably to create locally new forms of association between the academics of the two classical types of faculties : Law and Humanities.

Outside our academic world, another way for this development is to look for outside partnerships. Great private foundations we see in America do not existed in France. So, it is rather impossible to avoid public institutions, which also means political institutions. During five years (from 2011 to 2015), we have lead a new and original research program (the "regional observatory of crime and social context") in Marseille area, that associated AixMarseille University, the CNRS and the regional council. According to the agreement between those three institutions, the last one had given each year to the program a grant allowing to hire young investigators and develop a collective research program. Taking the review of this experience (Mucchielli, Raquet, 2016), we can say that it has been a real success for the rise of scientific knowledge and the local academic's dynamic. But the program has significantly stopped when the local elections had brought to power the conservative party. In such a institutional context, the extreme politicization of security questions (i.e. the absence of any consensus on it) is clearly a handicap for the development of our science.

\footnotetext{
${ }^{8}$ Despite the efforts of Xavier Pin, professor at the University of Lyon 3, in the animation of a "multidisciplinary conference of the research centers and qualifications leaders in criminology" during 2012 and 2013 (see the "Communiqué de la Conférence pluridisciplinaire des directeurs de centres de recherche et de diplômes en criminologie", Revue de sciences criminelles et de droit pénal comparé, 2012, 2, 469-472).
} 


\section{Reference list}

Bantigny, L. (2008). L'expertise et l'emprise. Construction et confrontation des savoirs sur les jeunes délinquants (1945-1975). in Caron J.-C., Stora-Lamarre A., Yvorel, J.-J. (Ed) Les âmes mal nées. Jeunesse et délinquance urbaine en France et en Europe (XIXe-XXe siècles) (pp. 187-199). Besançon : Presses universitaires de Franche-Comté.

Bauer, A. (ed), (2008). Déceler-Étudier-Former: une voie nouvelle pour la recherche stratégique. Rapport au Président de la République et au Premier ministre. publié dans les Cahiers de la sécurité, supplément au ${ }^{\circ} 4$.

Bauer, A. Raufer, X. Roucaute, Y. (2008). Une vocation nouvelle pour la criminologie. Sécurité globale, automne, 89-93.

Beirne, P. (1987). Between classicism and positivism : crime and penality in the writings of Gabriel Tarde. Criminology, 25 (4), 785-819.

Berthelet, P. (2014). Chaos international et sécurité globale. La sécurité en débats. Paris : Publibook.

Blanckaert, C. (1994). Des sauvages en pays civilisé. L'anthropologie des criminels (18501900). Mucchielli, L. (Ed.). Histoire de la criminologie française (pp. 55-88). Paris: L'Harmattan.

Borlandi, M. (2000). Tarde et les criminologues italiens de son temps. Revue d'histoire des sciences humaines, 3, 7-56.

Canguilhem, G. (1968). Études d'histoire et de philosophie des sciences. Paris: Vrin.

Chunnn D. Menziesn R. (2006). So what does all this have to do with criminology? Surviving the restructuration of the discipline in the twenty-first century. Canadian Journal of Criminology and Criminal Justice, 48 (5), 663-680.

Davidovitch, A. (1979). Le fonctionnement des parquets en France: recherche sur un mécanisme de régulation du système de justice pénale, in Le fonctionnement de la justice pénale. Paris : Éditions du CNRS, 65-100.

Debuyst, C., Digneffe, F., Pirès, A. (2008). Histoire des savoirs sur le crime et la peine, vol. 3 : Expliquer et comprendre la délinquance (1920-1960). Bruxelles: Larcier.

Dowbiggin, I. (1991). Inheriting Madness. Professionalization and Psychiatric Knowledge in Nineteenth-Century France. Oakland : University of California Press.

Enguéléguélé, S. (1998). Les politiques pénales (1958-1995). Paris: 1’Harmattan. 
Faget, J., \& Wyvekens, A. (1999). Bilan de la recherche sur le crime et la justice en France de 1990 à 1998. Van Outrive, L., \& Robert, Ph. (Eds). Crime et justice en Europe depuis 1990 (pp. 147-172). Paris: L’Harmattan.

Faugeron, C. (1991a). La production de l'ordre et le contrôle pénal. Bilan de la recherche en France depuis 1980. Déviance et société, 15 (1), 51-91.

Faugeron, C. (1991b). De la Libération à la guerre d'Algérie: l'espoir d'une réforme pénitentiaire. Petit, J.-G. (Ed.). Histoire des galères, bagnes, prisons (pp. 289-317). Toulouse: Privat.

Foucault, M. (1975). Surveiller et punir. Naissance de la prison. Paris : Gallimard.

Foucault, M. (1999). Les anormaux. Cours au Collège de France. Paris : Gallimard.

Garland, D. (2001). The culture of control. Crime and social order in contemporary society. Oxford: Oxford University Press.

Garland, D. Sparks, R. ed. (2000). Criminology and social theory, British Journal of Criminology, Special issue, 40 (2).

Gassin, R. (1991) Le droit pénal : droit public ou droit privé ?, J.-H. Robert (Ed.), Problèmes actuels de science criminelle (pp. 52-64), Presses Universitaires d'Aix-Marseille.

Hillyard, P. Pantazis, C. Tombs, S. Gordon, D. ed. (2004). Beyond Criminology: taking harm seriously. London: Pluto Press.

Jurmand, J.-P. (2016). Études et recherches à l'Éducation surveillée entre 1952 et 1972, instruments d'un renouveau institutionnel et professionnel, Sociétés et jeunesses en difficulté [En ligne], $\mathrm{N}^{\circ} 16$ | Printemps 2016. URL : http://sejed.revues.org/8044

Kaluszynski, M. (1994). Identités professionnelles, identités politiques : médecins et juristes face au crime au tournant du 19è et du 20è siècle. Mucchielli, L. (Ed.). Histoire de la criminologie française (pp. 215-235). Paris: L'Harmattan.

Kuhn, T. (2012). The Structure of Scientific Revolutions. Chicago : University of Chicago Press (4th ed.).

Lazerges, C. (Ed.) (1991). L'enseignement des sciences criminelles aujourd'hui, Toulouse: Érès.

Lefaucheur, N. (1994). Psychiatrie infantile et délinquance juvénile. Mucchielli, L. (Ed.). Histoire de la criminologie française (pp. 313-332). Paris: L'Harmattan.

Levasseur, G. (1991). L'influence de Marc Ancel sur la législation répressive française contemporaine. Revue de science criminelle et de droit pénal comparé, 1, 9-24.

Marcel, J.-C. (1999). Maurice Halbwachs à Chicago ou les ambigüités d'un rationalisme durkheimien. Revue d'histoire des sciences humaines. 1, 103-141. 
Marcel, J.-C., Mucchielli, L. (2002). La sociologie du crime en France depuis 1945. in Mucchielli, L. ; Robert, Ph. (ed.). Crime et sécurité : l'état des savoirs (pp. 53-63). Paris : La Découverte.

Marcel, J.-C., \& Mucchielli, L. (2006). André Davidovitch ou le deuxième âge de la sociologie criminelle en France, L'Année sociologique, 56 (1), 83-117.

Mouhanna, C. (2009). France : une lutte incessante autour de la recherche sur la police et le policing, in Ponsaers, P., Tange, C. \& Van Outrive, L. (ed), Regards sur la police (pp. 309328), Bruxelles : Bruylant.

Mucchielli, L. (1994a). Hérédité et "Milieu social" : le faux antagonisme franco-italien. La place de Lacassagne dans l'histoire de la criminologie. Mucchielli, L. (Ed.). Histoire de la criminologie française (pp. 189-214). Paris: L'Harmattan.

Mucchielli, L. (1994b) Naissance et déclin de la sociologie criminelle (1890-1940). in Mucchielli, L, (ed.) Histoire de la criminologie française (pp. 287-312). Paris : L'Harmattan.

Mucchielli, L. (1994c). Le sens du crime. Histoire des (r)apports de la psychanalyse à la criminologie. Mucchielli, L. (Ed.). Histoire de la criminologie française (pp. 351-409). Paris: L'Harmattan.

Mucchielli, L. (1997). Une sociologie militante du contrôle social. Naissance du projet et formation de l'équipe francophone, des origines au milieu des années quatre-vingt. Déviance et société, 21 (1), 7-45.

Mucchielli, L. (1998). La découverte du social. Naissance de la sociologie en France (18701914). Paris: La Découverte.

Mucchielli, L. (1999). Les champs de la sociologie pénale. Vingt ans de recherches et de débats dans “ Déviance et société ”. Déviance et société, 23 (1), 3-40.

Mucchielli, L. (2004). L'impossible constitution d'une discipline criminologique en France. Cadres institutionnels, enjeux normatifs et développements de la recherche des années 1880 à nos jours. Criminologie, 2004, 37 (1), 13-42.

Mucchielli, L. (2006). Criminology, hygienism and eugenics in France (1870-1914): the medical debates on the elimination of "incorrigible" criminals. Becker, P. \& Wetzell, R. (Eds.). Criminals and their scientists. The history of Criminology in International Perspective (pp. 207-230), Cambridge: Cambridge University Press.

Mucchielli, L. (2010). Vers une criminologie d'État en France ? Institutions, acteurs et doctrines d'une nouvelle science policière, Politix. Revue des sciences sociales du politique, 23 (1), 195-214. 
Mucchielli, L. (2014). Criminologie et lobby sécuritaire. Une controverse française. Paris: La Dispute.

Mucchielli, L. \& Raquet E. (Eds.) (2016). Délinquances, police, justice. Recherches à Marseille et en région PACA. Aix-en-Provence: Presses Universitaires de Provence.

Nye, R. (1984). Crime, Madness and Politics in Modern France. Princeton : Princeton University Press.

Pick, D. (1989). Faces of Degeneration. A European Disorder, c.1848-c.1918. Cambridge: Cambridge University Press.

Pinatel, J. (1957). Les données du problème de l'enseignement de la criminologie. Revue de science criminelle et de droit pénal comparé, 411-421.

Pinatel, J. (1960) La Criminologie. Paris : SPES.

Pires, A. (199) Le débat inachevé sur le crime : le cas du Congrès de 1950. Déviance et Société, 1, 23-46.

Renneville, M. (1995). Alexandre Lacassagne. Un médecin-anthropologue face à la criminalité. Gradhiva, 17, 127-140.

Renneville, M. (1997). La médecine du crime. Essai sur l'émergence d'un regard médical sur la criminalité en France (1785-1885). Lille: Presses Universitaires du Septentrion.

Renneville, M. (2003). Crime et folie. Deux siècles d'enquêtes médicales et judiciaires. Paris: Fayard.

Renouard, J.-M., \& Pradel, J., \& Boucher, N. (1992). La recherche française dans le champ pénal. Bilan et synthèse. Paris: CEDAS.

Rigouste, M. (2011) Les marchands de peur. La bande à Bauer et l'idéologie sécuritaire. Paris : Libertalia.

Robert, Ph. (1973) La sociologie entre une criminologie du passage à l'acte et une criminologie de la réaction sociale. L'Année Sociologique, 441-504.

Simon, J. (2007) Governing through crime. How the war on crime transformed American democraty and created a culture of fear. New York: Oxford University Press.

Soubiran-Paillet, F. (2000). Juristes et sociologues français d'après-guerre : une rencontre sans lendemain. Genèses, 41, 125-142.

Tétard, F. (1985). “Délinquance juvénile” : stratégie, concept ou discipline?. in Collectif. Problèmes de la jeunesse, marginalité et délinquance juvénile. Vol. 2 (pp. 125-147). Vaucresson: CFR-ES.

Topalov, P. (2006), Maurice Halbwachs et les sociologues de Chicago. Revue française de sociologie, 3, 561-590. 
Veilt, P. (1994). La géographie sociale du crime et la pratique réformatrice d'Henri Joly. Mucchielli, L. (Ed.). Histoire de la criminologie française (pp. 269-285). Paris: L'Harmattan.

Yvorel, J.-J. (2014). Au carrefour de la construction des savoirs sur la délinquance juvénile: le centre de recherche et de formation de Vaucresson (1951-1980), Criminocorpus, mis en ligne le 19 novembre 2014. URL : http://criminocorpus.revues.org/2735.

Zedner, L. (200) Pre-crime and post-criminology ?, Theoretical Criminology. 11 (2), 261-280. 